$\xi=\square$

\title{
Relationship between photosynthetically active radiation with global solar radiation using empirical model over selected climatic zones in Nigeria
}

\author{
Nwokolo Samuel Chukwujindu ${ }^{1 *}$, Ogbulezie Julie C. ${ }^{2}$, John-Jaja Sylvia Alwell ${ }^{3}$ \\ ${ }^{1}$ Department of Physics, Faculty of Physical Sciences, University of Calabar, Calabar, Nigeria \\ ${ }^{2}$ Department of Agriculture, School of Science and Technology, Babcock University, Ilisha-Remo, Nigeria \\ *Corresponding author E-mail: nwokolosc@stud.unical.edu.ng; sam31628@gmail.com
}

\begin{abstract}
In this study, relationship between photosynthetically active radiation (PAR) and global solar radiation (H) over selected climatic zones in Nigeria using 22-years data (July 1983 - June 2005) was analysed. Empirical model was employed as the baseline for theoretical formulation and estimation of the ratio of PAR/H over climatic zones in Nigeria. From the estimated values, the seasonal PAR/H ranged from 1.946-2.005, 1.909-1.955, 1.968-2.039, 1.987-2.060, 1.961-2.041, 1.928-1.984 and 1.946-2.005 in rainy season, and the high values were due to low influence from clearness index, harmattan dust and pyrogenic aerosols from regional biomass burning compared with 1.906-1.923, 1.905-1.917, 1.927-1.952, 1.950-1.999, 1.971-1.985 and 1.889-1.923 recorded in dry season as a result of combined high influence from cloudiness, pyogenic aerosols and harmattan dust with annual mean values of 1.943, 1.921, 1.975, 2.007, 1.986 and 1.936 for Ilorin, Sokoto, Abeokuta, Port Harcourt, Enugu and Gusau respectively. The annual ratio of PAR/H revealed that there is an evidence increase of the values from North-East (Gusau) to South-South (Port Harcourt). These variations were mainly due to trends in cloudiness and associated atmospheric moisture with the movement of the Hadley cell circulation system along the equatorial line. From the analysed results, the model was found suitable and meteorologically reliable to estimate PAR/H accurately from commonly available $\mathrm{H}$ data when compared with results within and beyond tropical locations in Nigeria.
\end{abstract}

Keywords: Photosynthetically Active Radiation; Clearness Index; Global Solar Radiation; Atmospheric Parameters and Nigeria.

\section{Introduction}

Photosynthetically active radiation (PAR) designates the spectral range (wave band) of solar radiation from $400-700 \mathrm{~nm}$ that photosynthetic organism are able to use in the process of photosynthesis. This spectral region corresponds more or less with the range of light visible to the human eye [1]. Photons at shorter wavelengths tend to be so energetic that they can be damaging to cells and tissues but are mostly filtered out by the ozone layer in the stratosphere photons at longer wavelengths do not carry enough energy to allow photosynthesis to take place [2]. Plants ultimately needs $\mathrm{PAR}$ as an energy requirement to convert carbon iv oxide $\left(\mathrm{CO}_{2}\right)$ and water $\left(\mathrm{H}_{2} \mathrm{O}\right)$ through photosynthesis into glucose which is used to synthesize structural and metabolic energy needed for plant growth, development, respiration as well as stored vegetative products that result in plant biomass [3], [4]. This can be seen in the process plants used in synthesizing their food as given by the chemical equation:

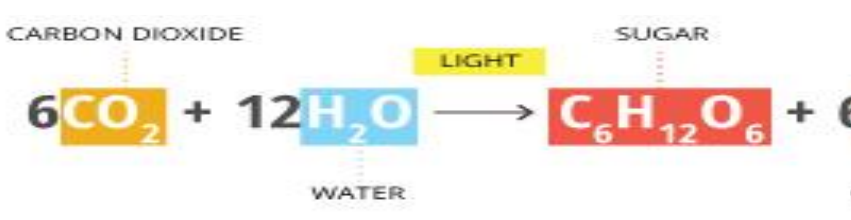

Where the light represents PAR wavelength range $(0.4-0.7 \mu \mathrm{m})$ that is best fit for photosynthesis to occur.

The accurate determination and clear understanding of the PAR fraction is required for many applications such as radiation forcing effect, energy management, hydrological process and biometeorology, crop production remote sensing of vegetation, carbon cycle modeling and calculating the euphotic depth in the ocean [1], [5]. With the increasing requirement to better understand the Earth's climate systems in the face of global change, more observations of

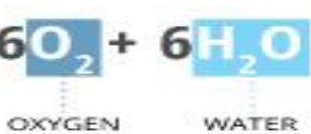

PAR are needed [6]. This radiometric flux varies from country to country and from place to place. It is a function of the regional sky clearness, which depends on the cloud and aerosol amount, sky brightness, which depends upon the aerosol burden and cloud thickness, solar elevation angle and precipitable water, accounting for the absorption effects that caused by the water vapour concentration [7-9].

Measurements of PAR have been performed in many parts of the world using a variety of techniques. These techniques have in- 
volved the use of Eppley precision spectral pyranometer (PSP), Li-COR quantum sensors (Li-190SZ) and PAR lite to mention but a few.

However, up till now, PAR measurements have not been carried out routinely at radiometric sites in Nigeria and other locations across the globe. To circumvent this problem, other methods for estimating PAR using currently available data such as MODIS (Moderate Resolution Imaging Spectroradiometer) has been used to calculate PAR values [10-11]. PAR can also been estimated using irradiative transfer models [5], [12]. Notwithstanding, the accuracy of these latter methods is not good enough for large areas [13-14].

Another widely used method is to estimate PAR from the routinely measured global solar radiation $(\mathrm{H})$ by considering the PAR fraction as a constant for a specific area [15-16]. The range of PAR fractions as reported in the literature suggest the desirability of local calibration to account for climatic and geographic differences such as cloudiness, day length and the diurnal pattern of solar radiation [17]. This problem necessitates PAR estimation by analyzing the characteristics of PAR with direct measured data, developing appropriate models for calculating PAR/H that can work well under various sky conditions in large areas. This will produce a large amount of appreciate PAR data without substantial cost [18-19].

A number of studies involving the relationship between PAR and $\mathrm{H}$ for different locations across the globe have been studied by different researchers. Zhou et al. [20] developed climatologically estimation of photosynthetically active quantum flux in Yucheng, China with average daily PAR/H value of 2.06. Papaioannou et al. [21] estimated PAR in Anthens with average daily PAR/H value of 1.94. Zhang et al. [22] measured and model PAR at Tibetan Plateau, Lhasa, China with an average daily PAR/H value of 1.95 . $\mathrm{Li}$ et al. [23] estimated the monthly ratios of PAR to measured $\mathrm{H}$ at northern Tibetan Plateau, China from 1.83-2.03. Gonzalez and Calbo [7] modeled and measured PAR/H under cloudless skies in Girona, Spain as 1.99. Jacovides et al. [16] related global PAR/H in the eastern Mediterrainean basin, Athalassa, Cyprus with an average daily value of 1.92 . Hu et al. [24] developed measurements and estimations of PAR in Beijing, China with an average daily value of 1.83 . Finch et al. [25] estimated PAR regimes in a southern African savannah environment, Lusaka, Zambia with an average daily value of 1.99. Wang et al. [5] established variation of PAR/H along altitude gradient in Naeba Mountain, Japan with an average daily value of 1.94. Xia et al. [26] analyzed photosynthetic photon flux density and its parameterization in Xianghe, China with average daily PAR/H value of 1.96 . Howell et al. [27] related PAR/H in the San Jaoaquin valley, California, USA with an average daily value of 2.058. Lunche et al. [28] developed $\mathrm{PAR} / \mathrm{H}$ in Wuhan, central China with an average value of 1.93.

The first available information and research published on the relationship between PAR/H in Nigeria was carried out by Udo and Aro [29] in Ilorin, central Nigeria. They obtained the average value of 2.08. Anjorin et al. [30] estimated hourly PAR/H in Jos, central Nigeria using Alados et al. [9] model and obtained an average value of 2.08 .

The objective of this study apart from determining the relationship between global photosynthetically active radiations with global radiation using empirical model over selected climatic zones in Nigeria, was to validate and recommend Alados et al. [9] model as a suitable and meteorologically reliable for estimating empirically ratio of $\mathrm{PAR} / \mathrm{H}$ in Nigeria.

\section{Materials and methods}

\subsection{Acquisition of data and study area}

The long term monthly mean daily global horizontal irradiation (H) for the period of 1983-2005 for the selected state capitals and locations whose tropical ecological zones, coordinates and elevations listed in Table 1 and Fig. 1 were obtained from the National Aeronautics and Space Administration (NASA) atmospheric science data center [32]. The $\mathrm{H}$ data measured in $\mathrm{kwhm}^{-2} \mathrm{day}^{-1}$ were converted to $\mathrm{MJm}^{-2} \mathrm{day}^{-1}$ using a factor of 3.6 [33] and was further converted to $\mathrm{EM}^{-1}$ using a converting factor of 4.56 [1]. The details of the study area are found in Nwokolo and Ogbulezie [31].

Table 1: States, State Capitals, Coordinates and Tropical Ecological Zones for the Selected Stations in Nigeria

\begin{tabular}{|c|c|c|c|c|c|}
\hline States & $\begin{array}{l}\text { State } \\
\text { Capitals }\end{array}$ & $\begin{array}{l}\text { Latitude } \\
\text { (Degree North) }\end{array}$ & $\begin{array}{l}\text { Longitude Elevation } \\
\text { (Degree East) }\end{array}$ & $\begin{array}{l}\text { Tropical Ecological } \\
\text { (Meters) }\end{array}$ & Zones \\
\hline Rivers & Port Harcourt & 4.75 & 7.00 & 117 & Mangrove Swamp \\
\hline Enugu & Enugu & 6.50 & 7.50 & 142 & Mangrove Swamp \\
\hline Ogun & Abeokuta & 7.05 & 3.32 & 66 & Tropical Rain Forest \\
\hline Kwara & Ilorin & 8.50 & 4.58 & 303 & Guinea Savannah \\
\hline Zamfara & Gusau & 12.07 & 6.638 & 415 & Sudan Savannah \\
\hline Sokoto & Sokoto & 13.067 & 5.233 & 331 & Sahel Savannah \\
\hline
\end{tabular}

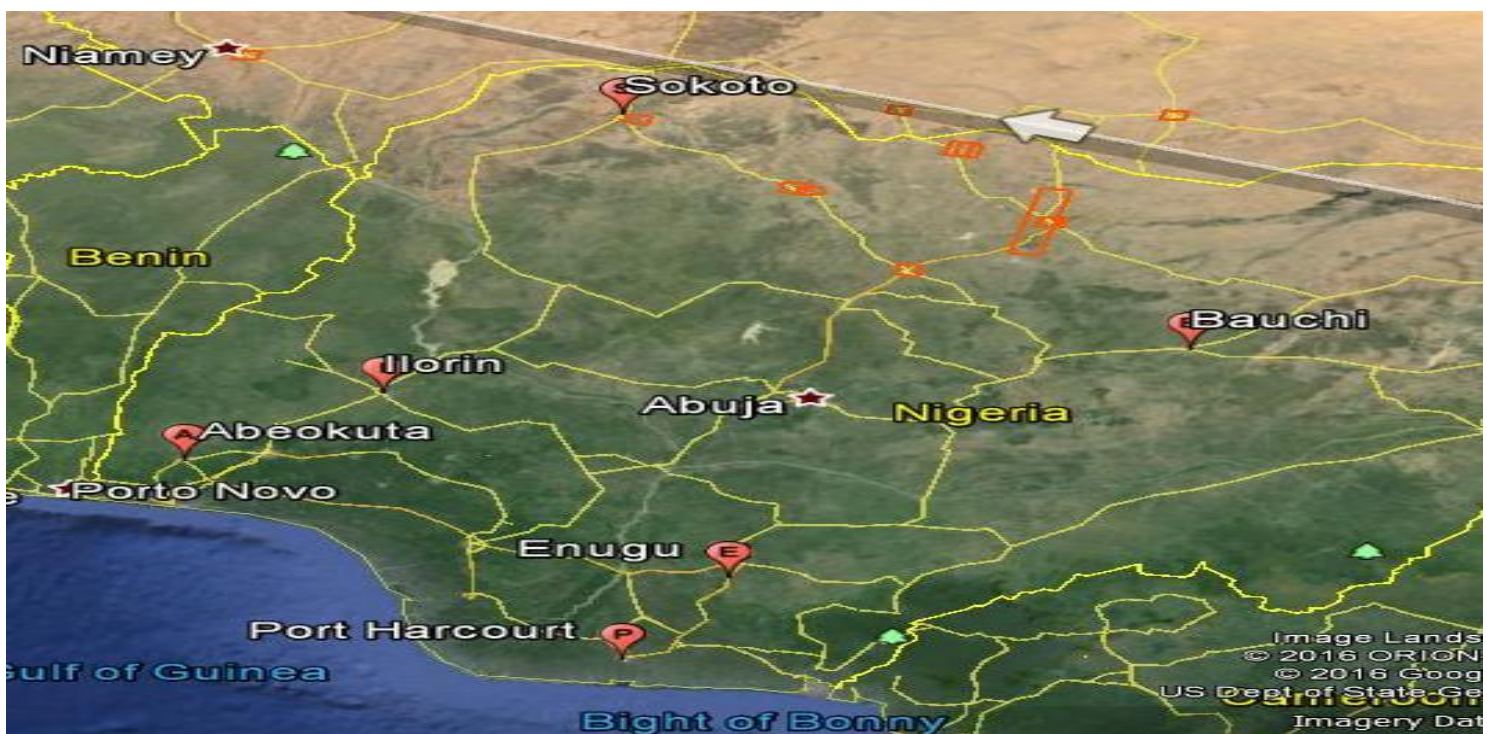

Fig. 1: Map of Nigeria Showing Study Locations (Port Harcourt, Enugu, Abeokuta, Ilorin, Gusua and Sokoto) 


\subsection{Evaluation procedures}

Various climatic parameters have been used in developing empirical relations for estimating the relationship between photosynthetically active radiation and global solar radiation. In this research, the simple model was Alados et al. [9] given as:

$$
\frac{P A R}{H}=1.832-0.191 \operatorname{In}_{t}+0.099 \sin \alpha
$$

Where $\mathrm{H}$ is the average monthly global solar radiation, PAR is the average monthly photosynthetically active radiation, $\mathrm{k}_{\mathrm{t}}$ is the clearness index, $\alpha$ is the solar altitude is related to zenith angle $\theta_{z}$ by the relation:

$\sin \alpha=\cos \theta_{z}$

The angle of incidence $\theta_{z}$ is the zenith angle of the sun estimated as:

$$
\cos \theta_{z}=\sin \delta \sin \varphi+\cos \delta \cos \varphi \cos \omega_{S}
$$

The extraterrestrial solar radiation on the horizontal surface was calculated and the expression given by Nwokolo et al. [3] as follows:

$$
H_{o}=\frac{24}{\pi} I_{S C}\left(\begin{array}{l}
1 \\
+0.033 \cos \frac{360 n}{365}
\end{array}\right) \times\left(\begin{array}{c}
\cos \varphi \cos \delta \sin \omega_{S} \\
2 \pi \omega_{S} \\
+\frac{360}{36 n} \sin \sin \delta
\end{array}\right)
$$

$I_{S C}$ is the solar constant, $\varphi$ is the latitude of the location, $\delta$ is the solar declination, $\omega_{S}$ is the mean sunrise hour angle for the given month and $\mathrm{n}$ the number of days of the year starting from first January. For a given month, the solar declination $\delta$ and the mean sunrise hour angle $\omega_{S}$ can be evaluated by the following equations

(6) and (7) respectively. $\delta=23.45 \sin \left[\frac{360(n+284)}{365}\right]$

$\omega_{S}=\cos ^{-1}[\tan \delta \tan \varphi]$

The average day length for each month was collected using the expression by Iqbal [33].

$$
\bar{N}=\frac{2}{15} \operatorname{Cos}^{-1}(-\tan \varphi \tan \delta)
$$

The clearness index is given by Iqbal [33] model expressed as:

$k_{t}=\frac{H}{H_{o}}$

Where all symbols retain their usual meaning.

The standard deviation (SD) for the PAR/H estimation was evaluated using the expression:

$S D=\sqrt{\frac{\sum\left(\frac{P A R}{H}-x\right)^{2}}{N}}$

Where $x$ is the monthly mean PAR from January to December, $\mathrm{N}$ is the total number of months in a year.

\section{Results}

The calculated values of monthly mean global solar radiation $\mathrm{H}$, extraterrestrial solar radiation $\mathrm{H}_{\mathrm{o}}$, clearness index $\mathrm{k}_{\mathrm{t}}$, characteristic day number $(\mathrm{N})$, standard deviation (SD) and ratio of Photosynthetically active radiation and global solar radiation $\mathrm{PAR} / \mathrm{H}$ obtained from Alados et al. [9] model over climatic zones in Nigeria

\begin{tabular}{|c|c|c|c|c|c|c|c|}
\hline Month & $\mathrm{N}$ & $\mathrm{H}\left(\mathrm{Kwhm}^{-2} \mathrm{day}^{-1}\right)$ & $\mathrm{H}\left(\mathrm{EMJ}^{-1}\right)$ & $\mathrm{H}_{\mathrm{o}}\left(\mathrm{EMJ}^{-1}\right)$ & $\mathrm{k}_{\mathrm{t}}$ & $\mathrm{PAR} / \mathrm{H}$ & SD $\left(\right.$ EMJ $\left.^{-1}\right)$ \\
\hline JAN & 17 & 5.17 & 84.88 & 157.25 & 0.5398 & 1.950 & 0.0165 \\
\hline FEB & 45 & 5.28 & 86.79 & 165.24 & 0.5253 & 1.955 & 0.0150 \\
\hline MAR & 74 & 4.86 & 79.81 & 171.22 & 0.4662 & 1.980 & 0.0080 \\
\hline APR & 105 & 4.62 & 75.89 & 170.48 & 0.4451 & 1.987 & 0.0058 \\
\hline MAY & 135 & 4.04 & 66.35 & 164.69 & 0.4029 & 2.010 & 0.0009 \\
\hline JUN & 161 & 3.08 & 50.61 & 160.31 & 0.3157 & 2.052 & 0.0130 \\
\hline JUL & 199 & 2.99 & 49.06 & 161.72 & 0.3033 & 2.060 & 0.0153 \\
\hline AUG & 2329 & 3.36 & 55.12 & 167.06 & 0.3300 & 2.044 & 0.0107 \\
\hline SEP & 261 & 3.24 & 53.25 & 169.89 & 0.3135 & 2.054 & 0.0136 \\
\hline OCT & 292 & 3.45 & 56.63 & 166.15 & 0.3408 & 2.038 & 0.0089 \\
\hline NOV & 322 & 4.02 & 66.17 & 158.44 & 0.4176 & 1.999 & 0.0023 \\
\hline DEC & 347 & 4.81 & 78.95 & 154.01 & 0.5126 & 1.960 & 0.0136 \\
\hline MEAN & & 4.08 & 66.96 & 163.87 & 0.4094 & 2.007 & 0.0103 \\
\hline
\end{tabular}
are presented in Tables (2-7).

Table 2: Monthly Mean Daily Values of Global Solar Radiation $(\mathrm{H})$, Extraterrestrial Solar Radiation $\left(\mathrm{H}_{\mathrm{o}}\right)$, Clearness Index $\left(\mathrm{K}_{\mathrm{t}}\right)$, Characteristic Day Number (N), Ratio of Photosynthetically Active Radiation and Global Solar Radiation PAR/H and Standard Deviation (SD) for Port Harcourt (1983-2005) 
Table 3: Monthly Mean Daily Values of Global Solar Radiation $(\mathrm{H})$, Extraterrestrial Solar Radiation $\left(\mathrm{H}_{\mathrm{o}}\right)$, Clearness Index $\left(\mathrm{K}_{\mathrm{t}}\right)$, Characteristic Day Number (N), Ratio of Photosynthetically Active Radiation and Global Solar Radiation PAR/Hand Standard Deviation (SD) for Enugu (1983-2005)

\begin{tabular}{|c|c|c|c|c|c|c|c|}
\hline Month & $\mathrm{N}$ & $\mathrm{H}\left(\mathrm{Kwhm}^{-2} \mathrm{day}^{-1}\right)$ & $\mathrm{H}\left(\mathrm{EMJ}^{-1}\right)$ & $\mathrm{H}_{\mathrm{o}}\left(\mathrm{EMJ}^{-1}\right)$ & $\mathrm{k}_{\mathrm{t}}$ & $\mathrm{PAR} / \mathrm{H}$ & $\mathrm{SD}\left(\mathrm{EMJ}^{-1}\right)$ \\
\hline JAN & 17 & 4.47 & 73.42 & 163.59 & 0.4492 & 1.985 & 0.0003 \\
\hline FEB & 45 & 4.90 & 80.54 & 168.89 & 0.4769 & 1.973 & 0.0038 \\
\hline MAR & 74 & 5.01 & 82.37 & 171.31 & 0.4808 & 1.972 & 0.0040 \\
\hline APR & 105 & 2.38 & 84.69 & 166.29 & 0.5093 & 1.961 & 0.0072 \\
\hline MAY & 135 & 4.98 & 81.82 & 157.02 & 0.5211 & 1.966 & 0.0058 \\
\hline JUN & 161 & 4.33 & 71.14 & 151.27 & 0.4703 & 1.976 & 0.0029 \\
\hline JUL & 199 & 3.95 & 64.94 & 159.03 & 0.4083 & 2.003 & 0.0075 \\
\hline AUG & 2329 & 3.99 & 65.57 & 161.86 & 0.4051 & 2.005 & 0.0055 \\
\hline OCT & 292 & 4.05 & 66.53 & 172.17 & 0.3864 & 2.041 & 0.0159 \\
\hline NOV & 322 & 4.80 & 78.90 & 163.50 & 0.4826 & 1.971 & 0.0043 \\
\hline DEC & 347 & 4.57 & 75.11 & 160.72 & 0.4673 & 1.977 & 0.0026 \\
\hline MEAN & & 4.31 & 74.46 & 163.69 & 0.4558 & 1.986 & 0.0053 \\
\hline
\end{tabular}

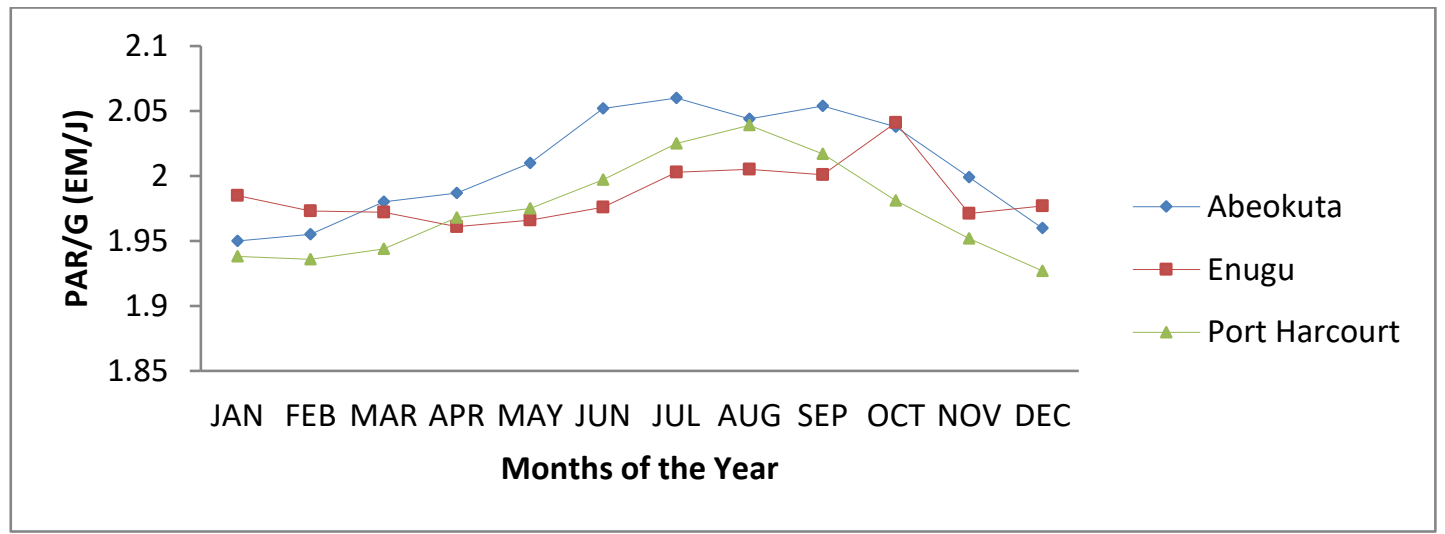

Fig. 2: Comparison between the Ratios of Estimated PAR/H for Abeokuta, Enugu and Port Harcourt.

Table 4: Monthly Mean Daily Values of Global Solar Radiation $(\mathrm{H})$, Extraterrestrial Solar Radiation $\left(\mathrm{H}_{\mathrm{o}}\right)$, Clearness Index $\left(\mathrm{K}_{\mathrm{t}}\right)$, Characteristic Day Number (N), Ratio of Photosynthetically Active Radiation and Global Solar Radiation PAR/Hand Standard Deviation (SD) for Abeokuta (1983-2005)

\begin{tabular}{|c|c|c|c|c|c|c|c|}
\hline Month & $\mathrm{N}$ & $\mathrm{H}\left(\mathrm{Kwhm}^{-2} \mathrm{day}^{-1}\right)$ & $\mathrm{H}\left(\mathrm{EMJ}^{-1}\right)$ & $\mathrm{H}_{\mathrm{o}}\left(\mathrm{EMJ}^{-1}\right)$ & $\mathrm{k}_{\mathrm{t}}$ & $\mathrm{PAR} / \mathrm{H}$ & $\mathrm{SD}\left(\mathrm{EMJ}^{-1}\right)$ \\
\hline JAN & 17 & 5.52 & 90.67 & 161.31 & 0.5621 & 1.938 & 0.0107 \\
\hline FEB & 45 & 5.63 & 92.54 & 161.68 & 0.5724 & 1.936 & 0.0113 \\
\hline MAR & 74 & 5.76 & 94.55 & 169.94 & 0.5564 & 1.944 & 0.0089 \\
\hline APR & 105 & 5.17 & 84.97 & 171.76 & 0.4947 & 1.968 & 0.0020 \\
\hline MAY & 135 & 4.93 & 81.00 & 167.88 & 0.4825 & 1.975 & 0.0001 \\
\hline JUN & 161 & 4.32 & 71.00 & 164.42 & 0.4319 & 1.997 & 0.0064 \\
\hline JUL & 199 & 3.94 & 61.42 & 165.42 & 0.3713 & 2.025 & 0.0144 \\
\hline AUG & 2329 & 3.52 & 57.82 & 169.57 & 0.3419 & 2.039 & 0.0185 \\
\hline SEP & 261 & 3.91 & 64.30 & 169.57 & 0.3792 & 2.017 & 0.0121 \\
\hline OCT & 292 & 4.52 & 74.20 & 163.27 & 0.4544 & 1.981 & 0.0017 \\
\hline NOV & 322 & 5.09 & 83.60 & 153.74 & 0.5438 & 1.952 & 0.0066 \\
\hline DEC & 347 & 5.39 & 88.48 & 148.49 & 0.5959 & 1.927 & 0.0139 \\
\hline MEAN & & 4.79 & 78.71 & 163.88 & 0.4822 & 1.975 & 0.0089 \\
\hline
\end{tabular}

Table 5: Monthly Mean Daily Values of Global Solar Radiation $(\mathrm{H})$, Extraterrestrial Solar Radiation $\left(\mathrm{H}_{\mathrm{o}}\right)$, Clearness Index $\left(\mathrm{K}_{\mathrm{t}}\right)$, Characteristic Day Number $(\mathrm{N})$, Ratio of Photosynthetically Active Radiation and Global Solar Radiation PAR/Hand Standard Deviation (SD) for Ilorin (1983-2005)

\begin{tabular}{|c|c|c|c|c|c|c|c|}
\hline Month & $\mathrm{N}$ & $\mathrm{H}\left(\mathrm{Kwhm}^{-2} \mathrm{day}^{-1}\right)$ & $\mathrm{H}\left(\mathrm{EMJ}^{-1}\right)$ & $\mathrm{H}_{\mathrm{o}}\left(\mathrm{EMJ}^{-1}\right)$ & $\mathrm{k}_{\mathrm{t}}$ & PAR/H & SD $\left(E^{-1}{ }^{-1}\right)$ \\
\hline JAN & 17 & 5.73 & 94.10 & 146.57 & 0.6420 & 1.917 & 0.0075 \\
\hline FEB & 45 & 5.99 & 98.52 & 157.62 & 0.6251 & 1.922 & 0.0065 \\
\hline MAR & 74 & 6.36 & 105.0 & 168.34 & 0.6208 & 1.923 & 0.0058 \\
\hline APR & 105 & 6.06 & 99.57 & 172.68 & 0.5766 & 1.934 & 0.0026 \\
\hline MAY & 135 & 5.74 & 92.28 & 170.85 & 0.5518 & 1.946 & 0.0009 \\
\hline JUN & 161 & 5.08 & 83.46 & 168.29 & 0.4959 & 1.966 & 0.0066 \\
\hline JUL & 199 & 4.52 & 74.24 & 168.84 & 0.4397 & 1.989 & 0.0133 \\
\hline AUG & 2329 & 4.21 & 69.23 & 170.85 & 0.4052 & 2.005 & 0.0179 \\
\hline SEP & 261 & 4.84 & 79.58 & 164.28 & 0.4844 & 2.004 & 0.0176 \\
\hline OCT & 292 & 5.36 & 88.12 & 160.00 & 0.5508 & 1.946 & 0.0009 \\
\hline NOV & 322 & 5.78 & 94.92 & 148.54 & 0.6393 & 1.918 & 0.0072 \\
\hline DEC & 347 & 5.88 & 96.65 & 142.47 & 0.6784 & 1.906 & 0.0107 \\
\hline MEAN & & 5.46 & 83.52 & 161.61 & 0.5578 & 1.943 & 0.0081 \\
\hline
\end{tabular}




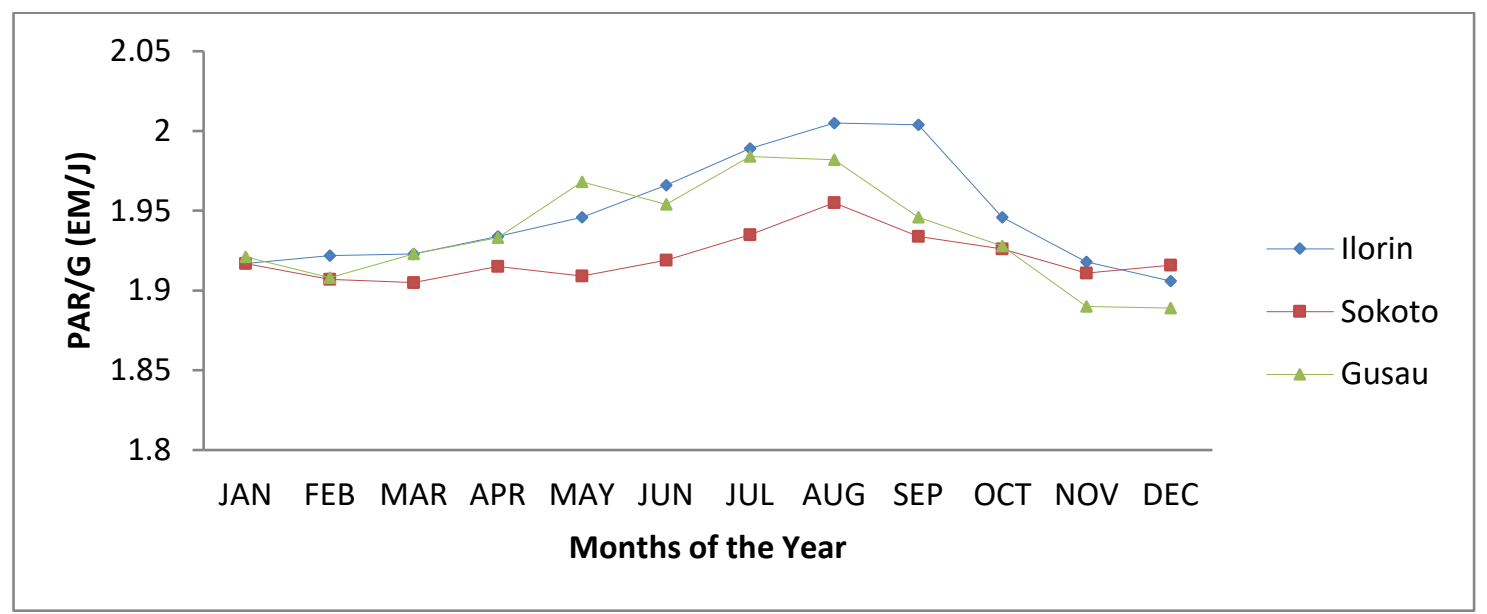

Fig. 3: Comparison between the Ratios of Estimated PAR/H for Ilorin, Sokoto and Gusau.

Table 6: Monthly Mean Daily Values of Global Solar Radiation (H), Extraterrestrial Solar Radiation $\left(\mathrm{H}_{\mathrm{o}}\right)$, Clearness Index $\left(\mathrm{K}_{\mathrm{t}}\right)$, Characteristic Day Number (N), Ratio of Photosynthetically Active Radiation and Global Solar Radiation PAR/Hand Standard Deviation (SD) for Sokoto (1983-2005)

\begin{tabular}{|c|c|c|c|c|c|c|c|}
\hline & $\mathrm{N}$ & $\mathrm{H}\left(\mathrm{Kwhm}^{-2} \mathrm{day}^{-1}\right)$ & $\mathrm{H}\left(\mathrm{EMJ}^{-1}\right)$ & $\mathrm{H}_{\mathrm{o}}\left(\mathrm{EMJ}^{-1}\right)$ & $\mathrm{k}_{\mathrm{t}}$ & $\mathrm{PAR} / \mathrm{H}$ & SD $\left(E^{-1}\right)$ \\
\hline JAN & 17 & 5.40 & 88.66 & 138.40 & 0.6406 & 1.917 & 0.0012 \\
\hline FEB & 45 & 6.24 & 102.5 & 152.19 & 0.6741 & 1.907 & 0.0040 \\
\hline MAR & 74 & 6.89 & 113.1 & 165.65 & 0.6832 & 1.905 & 0.0046 \\
\hline APR & 105 & 7.14 & 117.3 & 173.31 & 0.6767 & 1.915 & 0.0017 \\
\hline MAY & 135 & 7.08 & 116.2 & 174.09 & 0.6679 & 1.909 & 0.0035 \\
\hline JUN & 161 & 6.68 & 109.9 & 172.68 & 0.6361 & 1.919 & 0.0006 \\
\hline JUL & 199 & 6.14 & 100.9 & 172.68 & 0.5843 & 1.935 & 0.0040 \\
\hline AUG & 2329 & 5.51 & 90.49 & 172.54 & 0.5245 & 1.955 & 0.0098 \\
\hline SEP & 261 & 5.96 & 97.93 & 167.43 & 0.5849 & 1.934 & 0.0038 \\
\hline OCT & 292 & 5.79 & 95.05 & 155.47 & 0.6114 & 1.926 & 0.0041 \\
\hline NOV & 322 & 5.73 & 94.05 & 141.83 & 0.6631 & 1.911 & 0.0029 \\
\hline DEC & 347 & 5.30 & 87.07 & 134.85 & 0.6457 & 1.916 & 0.0014 \\
\hline MEAN & & 6.16 & 101.1 & 160.09 & 0.6327 & 1.921 & 0.0032 \\
\hline
\end{tabular}

Table 7: Monthly Mean Daily Values of Global Solar Radiation $(\mathrm{H})$, Extraterrestrial Solar Radiation $\left(\mathrm{H}_{\mathrm{o}}\right)$, Clearness Index $\left(\mathrm{K}_{\mathrm{t}}\right)$, Characteristic Day Number $(\mathrm{N})$, Ratio of Photosynthetically Active Radiation and Global Solar Radiation PAR/Hand Standard Deviation (SD) for Gusau (1983-2005)

\begin{tabular}{|c|c|c|c|c|c|c|c|}
\hline Month & $\mathrm{N}$ & $\mathrm{H}\left(\mathrm{Kwhm}^{-2} \mathrm{day}^{-1}\right)$ & $\mathrm{H}\left(\mathrm{EMJ}^{-1}\right)$ & $\mathrm{H}_{\mathrm{o}}\left(\mathrm{EMJ}^{-1}\right)$ & $\mathrm{k}_{\mathrm{t}}$ & $\mathrm{PAR} / \mathrm{H}$ & SD $\left(\mathrm{EMJ}^{-1}\right)$ \\
\hline JAN & 17 & 5.41 & 88.23 & 141.83 & 0.6263 & 1.921 & 0.0043 \\
\hline FEB & 45 & 6.38 & 104.9 & 153.24 & 0.6730 & 1.908 & 0.0081 \\
\hline MAR & 74 & 6.33 & 104.0 & 166.70 & 0.6241 & 1.923 & 0.0038 \\
\hline APR & 105 & 6.21 & 102.1 & 173.50 & 0.5883 & 1.933 & 0.0009 \\
\hline MAY & 135 & 5.38 & 88.44 & 180.07 & 0.4911 & 1.968 & 0.0092 \\
\hline JUN & 161 & 5.83 & 95.69 & 180.75 & 0.5294 & 1.954 & 0.0052 \\
\hline JUL & 199 & 4.71 & 77.44 & 171.90 & 0.4506 & 1.984 & 0.0139 \\
\hline AUG & 2329 & 4.76 & 78.12 & 171.72 & 0.4550 & 1.982 & 0.0133 \\
\hline SEP & 261 & 5.59 & 91.92 & 167.34 & 0.5493 & 1.946 & 0.0029 \\
\hline OCT & 292 & 5.72 & 94.00 & 155.33 & 0.6053 & 1.928 & 0.0023 \\
\hline NOV & 322 & 6.42 & 105.5 & 142.24 & 0.7413 & 1.890 & 0.0133 \\
\hline DEC & 347 & 6.18 & 101.4 & 136.35 & 0.7441 & 1.889 & 0.0136 \\
\hline MEAN & & 5.74 & 94.32 & 161.75 & 0.5898 & 1.936 & 0.0076 \\
\hline
\end{tabular}

Table 8: Monthly, Maximum, Minimum, Seasonal and Annual Mean Daily Values of Global Solar Radiation $(\mathrm{H})$, Extraterrestrial Solar Radiation $\left(\mathrm{H}_{\mathrm{o}}\right)$, Clearness Index $\left(\mathrm{K}_{\mathrm{t}}\right)$, Characteristic Day Number $(\mathrm{N})$, Ratio of Photosynthetically Active Radiation and Global Solar Radiation PAR/Hand Standard Deviation $(S D)$ for Sokoto, Gusau, Ilorin, Abeokuta, Enugu and Port Harcourt (1983-2005)

\begin{tabular}{llllll}
\hline Parameters & Sokoto & Gusau & Ilorin & Abeokuta & Enugu \\
\hline $\mathrm{H}_{\left(\text {EMJ }^{-1}\right)}$ & 101.11 & 94.32 & 83.52 & 78.46 & 74.46 \\
$\mathrm{H}_{\mathrm{o}}\left(\mathrm{EMJ}^{-1}\right)$ & 160.1 & 161.8 & 161.6 & 163.8 & 163.7 \\
$\mathrm{k}_{\mathrm{t}}$ & 0.633 & 0.590 & 0.558 & 0.482 & 0.409 \\
PAR/H (MAX) & 1.955 & 1.984 & 2.005 & 2.039 & 2.005 \\
PAR/H (MIN) & 1.905 & 1.889 & 1.960 & 1.927 & 1.981 \\
PAR/H (RAINY) & 1.931 & 1.956 & 1.967 & 1.995 & 1.983 \\
PAR/H (DRY) & 1.914 & 1.909 & 1.922 & 1.947 & 1.989 \\
PAR/H (ANNUAL) & 1.921 & 1.936 & 1.943 & 1.975 & 1.986 \\
SD (EMJ $\left.{ }^{-1}\right)$ & 0.003 & 0.008 & 0.008 & 0.009 & 0.090 \\
\hline
\end{tabular}




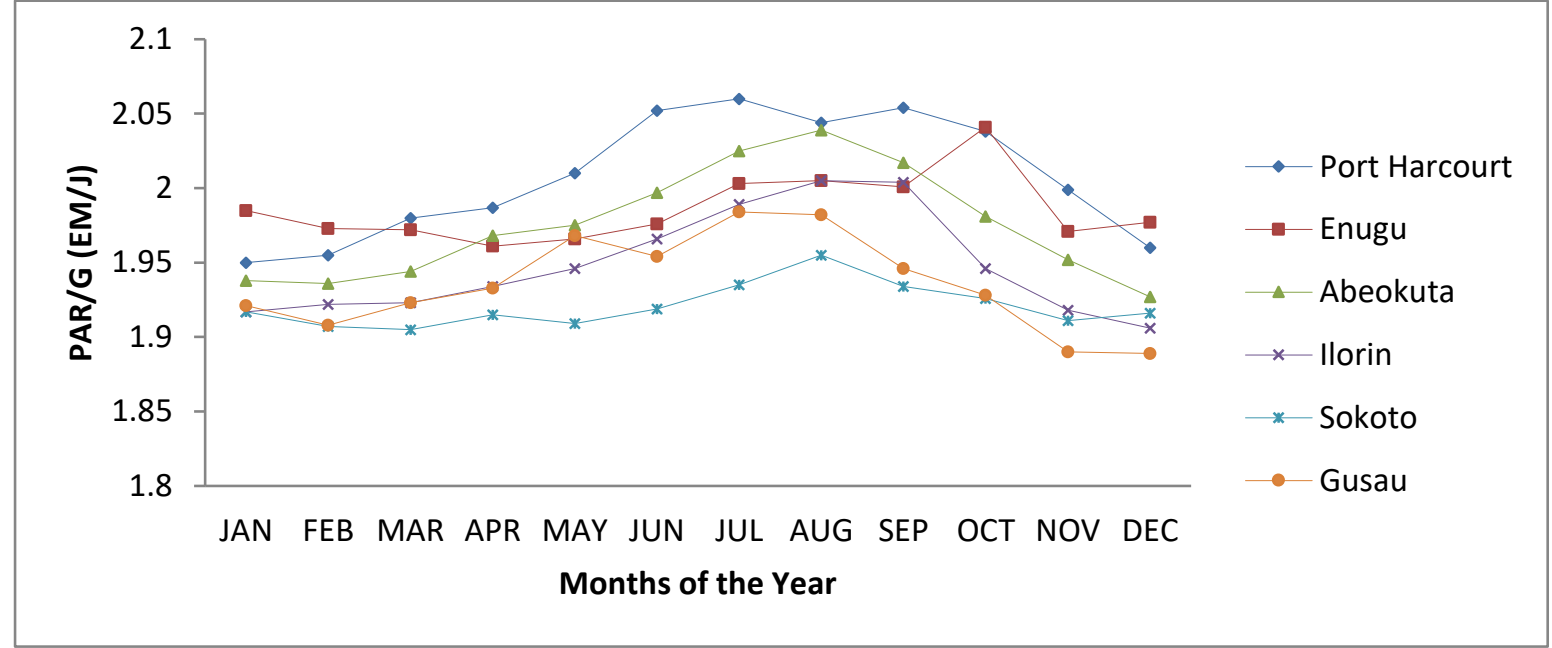

Fig. 4: Comparison between the Ratios of Estimated PAR/H for Port Harcourt, Enugu, Abeokuta, Ilorin, Sokoto. Gusau.

\section{Discussions}

A close look at Table $2-7$ and Figure $2-4$ shows that the maximum value of the monthly mean PAR/H registered 2.005, 1.955, 1.984, 2.039, 2.00 and 2.060 for Ilorin, Sokoto, Gusau, Abeokuta, Enugu and Port Harcourt respectively and they occurred within months of July and August. These values and months of occurrence are within what is expected of a tropical site [29], [34]. These months are characterized by heavy rainfall, wet atmosphere, presence of cloud, low values of clearness index, harmattan dust and pyrogenic aerosols from regional biomass burning. These factors enhanced PAR/H values through absorption by the precipitated water vapour, reflection and absorption by clouds [35], [36]. The range of values obtained from this study is comparable to 2.08 observed in Ilorin, Nigeria by Udo and Aro [29]; 1.94 reported in Athalassu, Cyprus by Jacovide et al. [16]; 1.98 recorded in Beijing, China by $\mathrm{Hu}$ et al. [24]; 2.08 reported by Xia et al. [26], Xiaugh, China.

The minimum values of the monthly mean PAR/H reported 1.906 1.905, 1.889, 1.927, 1.981, 1.950 for Ilorin, Sokoto, Gusau, Abeokuta, Enugu and Port Harcourt respectively and they occur within the months of December, January, March and April. These values are within what is expected of a tropical site [29], [34]. These months of occurrence is expected for Ilorin (December), Gusau (December), Abeokuta (December), Port Harcourt (January), because of the Hamattan season when aerosol mass loading, dry atmosphere and the presence of clear skies greatly reduces the intensity of PAR/H [35], [36]. However, the months of occurrence for Sokoto (March) and Enugu (April) is not expected which could be attributed to prolonged dry seasons annually in the two locations. The range of values obtained in this study agreed favourably with 1.92 observed in Ilorin, Nigeria by Udo and Aro [29]; 1.86 reported in Athalass, Cyprus by Jacovide et al. [16]; 1.77 recorded in Beijing, China by $\mathrm{Hu}$ et al. [24]; 1.87 obtained in Xianghe, China by Xia et al. [26].

The values of the mean monthly PAR/H recorded 1.922, 1.914, $1.909,1.947,1.989$ and 1.980 for the dry season in Ilorin (NorthCentral), Sokoto (North-West), Gusau (North-East), Abeokuta (South-West), Enugu (South-East) and Port Harcourt (SouthSouth) respectively. These values are within the range of what is expected of a tropical site [29], [34]. The range of values obtained are equally comparable to 1.94 reported in the dry season in Ilorin, Nigeria by Udo and Aro[29], and 1.78 observed in the dry season in Wuhua, China by Lunche et al. [28].

The mean monthly PAR/H reported $1.967,1.931,1.956,1.945$, 1.983 and 2.027 for the rainy season for Ilorin (North-Central), Sokoto (North-West), Gusau (North-East), Abeokuta (SouthWest), Enugu (South-East) and Port Harcourt (South-South) respectively. The values of the PAR/H ratio for rainy season is high- er than dry season because the absorption of solar radiation in the portion of the solar spectrum is enhanced whereas absorption in the PAR wavelength does not vary significantly, thus resulting in increasing value of $\mathrm{PAR} / \mathrm{H}$ under cloudy skies. Also, with the movement of the ITCZ into the Northern hemisphere, the rainbearing South westerlies prevail as far as possible to bring rainfall during the rainy season. The implication is that there is a prolonged rainy season in the far South, while the far North undergoes long dry periods annually. The value obtained is equally comparable to 1.95 observed by Lunche et al. [28] and 2.12 reported by Udo and Aro [29] in Ilorin, Nigeria.

The actual values of the annual mean daily $\mathrm{PAR} / \mathrm{H}$ ratio of all the zones recorded 1.943, 1.921, 1.936, 1.975, 1.986, 2.007 for Ilorin (North-Central), Sokoto (North-West), Gusau (North-East), Abeokuta (South-West), Enugu (South-East) and Port Harcourt (SouthSouth) respectively. The values are within the range of what is expected of a tropical site [29], [34]. The range of values obtained also agreed favourably with other authors within and across the globe. Zhou et al. [20] reported 2.06 in Yucheug, China; 1.94 was observed by Papaioannou et al. [21] in Athens, Greece; 1.95 was obtained by Zhang et al. [22] in Lhasoi, China. Li et al. [23] observed 2.0 in Northern Tibetau; Gonzalez and Calbo [7] estimated 1.99 in Girona, Spain; 1.92 obtained by Jacovides et al. [23] in Athalussa, Cyprus; 1.83 reported by Hu et al. [24] in Beijing, China; 1.99 observed by Finch et al. [25] in Lusaka, Zambia; 1.94 obtained by Wang et al. [5] in Naeba Mountain, Japan; 1.96 reported by Xia et al. [26] in Xianghe, China; 2.058 observed by Howell et al. [27]1983) in California, USA.

The annual mean values of $\mathrm{PAR} / \mathrm{H}$ ratio in different locations under different climatic zones indicates an evidence increase from 1.921-2.007 between Sokoto (North-West) to Port Harcourt (South-South). These evidence variations were mainly due to trends in cloudiness and associated atmospheric moisture with the movement of the Hadley cell circulation system along the equatorial line.

Table 8 shows that the monthly mean values of global solar radiation $(\mathrm{H})$ in different locations under different climatic zones increased as the latitude increases from the Port Harcourt (SouthSouth) to Sokoto (North-West). These evidence variations were mainly due to trend in cloudiness and associated with the movement of the Hadley cell circulation system along the equatorial line.

\section{Conclusion}

Higher mean values of $\mathrm{PAR} / \mathrm{H}$ ratio were observed during rainy season with increasing sequence from North-West to South-South climatic zones while in dry season, the mean values were lower with increasing sequence from North-West to South-South climate zones. This evidence variation is due to the movement of the ITCZ 
into the Northern hemisphere in the rain-bearing South westerlies thereby prevails as far inland as possible to bring rainfall during the rainy season. This resulted in prolonged rainy season in the far South, while the far North undergoes long dry periods annually. The average annual values of PAR/H ratio equally increased from North-West to South-South climatic zones. This variation was mainly due to trends in cloudiness and associated with atmospheric moisture with the movement of the Hadley cell circulation system along the equatorial line.

\section{Acknowledgement}

Our thanks go to the NASA Langley Research Center Atmospheric Science Data Center Surface meteorological and Solar Energy (SSE) web portal supported by the NASA LaRC POWER Project for the data used for this research paper. We also wish to thank all the authors cited in this paper for their research works that has made this research possible.

\section{References}

[1] McCree K. (1972). Test of current definitions of photosynthetically active radiation against leaf photosynthesis data. Agric Meteorol 10:443-453. https://doi.org/10.1016/0002-1571(72)90045-3.

[2] Gates DM. (1980). Biophysical Ecology. Third Ed. Spinger-Verlag, New York. https://doi.org/10.1007/978-1-4612-6024-0.

[3] Nwokolo SC, Ogbulezie JC. Toge CK, John-Jaja SA. (2016). Modeling the Influence of Relative Humidity on Photosynthetically Active Radiation from Global Horizontal Irradiation in Six Tropical Ecological Zones in Nigeria. N Y Sci J, 9(11):40-55.

[4] Nwokolo SC, Ogbulezie JC, Toge CK, John-Jaja SA. (2017). Photosynthetically active radiation estimation and modeling over different climatic zones in Nigeria. Journal of Agriculture and Ecology research International,http://sciencedomain.org/journal/37/articlespress.

[5] Wang Q, Kakubari Y, Kubota M, Tenhunen J (2007). Variation of PAR to global solar radiation ratio along altitude gradient in Naeba Mountain. Theor Appl Climatol, 87:239-253. https://doi.org/10.1007/s00704-005-0220-6.

[6] Clay GD, Worrall F, Rose R (2010). Carbon budgets of an upland blanket bog managed by prescribed fire. J Geophys Res, 115: G04037. https://doi.org/10.1029/2010JG001331.

[7] Gonzalez JA, Calbo J (2002). Modeled and measured ratio of PAR to global radiation under cloudless skies. Agric For Meteorol, 110:319-325. https://doi.org/10.1016/S0168-1923(01)00291-X.

[8] Tsubo M, Walker S (2005). Relationships between photosynthetically active radiation and clearness index at Bloemfontein, South Africa. Theor Appl Climatol, 80:17-25. https://doi.org/10.1007/s00704-004-0080-5.

[9] [9] Alados I, Moreno IF, Arboledas LA. (1996). Photosynthetically active radiation: measurements and modelling. Agric For Meteorol, 178:121-131.

[10] Van PE, Sanchez GA (2005). Mapping PAR using MODIS atmosphere products. Remote Sens Environ, 94:554-563. https://doi.org/10.1016/j.rse.2004.11.011.

[11] Liu RG, Liang SL, He HL, Liu JY, Zheng T (2008). Mapping incident photosynthetically active radiation from MODIS data over China. Remote Sens Environ, 112:998-1009. https://doi.org/10.1016/j.rse.2007.07.021.

[12] Joshi KB, Costello JH, Priya S (2011). Estimation of Solar Energy Harvested for Autonomous Jellyfish Vehicles (AJVs). IEEE J Oceanic Eng 36:539-551. https://doi.org/10.1109/JOE.2011.2164955.

[13] JanjaiS, Wattan R (2011). Development of a model for the estimation of photosynthetically active radiation from geostationary satellite data in a tropical environment. Remote Sens Environ 115:16801693. https://doi.org/10.1016/j.rse.2011.02.026.

[14] Gao ZQ, Xie XP, Gao W, Chang NB (2011). Spatial analysis of terrain impacted Photosynthetic Active Radiation (PAR) using MODIS data. GIScience Remote Sens 48:501-521. https://doi.org/10.2747/1548-1603.48.4.501.

[15] Mayer H, Holst T, Schindler D (2002). Microclimate within beech stands-Part 1: photosynthetically active radiation. Forst $\mathrm{w} \mathrm{Cbl}$ 121:301-321. https://doi.org/10.1046/j.1439-0337.2002.02038.x.

[16] Jacovides CP, Tymvios FS, Asimakopoulos DN, Pashiardes S (2003). Global photosynthetically active radiation and its relationship with global solar radiation in the eastern Mediterranean basin.
Theor Appl Climatol, 74:227-233. https://doi.org/10.1007/s00704002-0685-5.

[17] Aguiar LJG, Fischer GR, Ladle RJ, Malhado AC, Aguiar RG. (2012). Modeling the photosynthetically active radiation in South West Amazonia under all sky conditions. Theor Appl Climatol, 108 631-640. https://doi.org/10.1007/s00704-011-0556-z.

[18] Etuk ES, Nwokolo SC, Okechukwu AE, John-Jaja SA. (2016a). Analysis of photosynthetically active radiation over six tropical ecological zones in Nigeria; Journal of Geography, Environment and Earth Science International, 7(4): 1-15.

[19] Etuk ES, Nwokolo SC, Okechukwu AE. (2016b). Modelling and estimating photosynthetically active radiation from measured global solar radiation at Calabar, Nigeria. Physical Science International Journal, 12(2):1-12. https://doi.org/10.9734/PSIJ/2016/28446.

[20] Zhou Y, Xiang Y, Luan L (1996). Climatological estimation of photosynthetically active quantum flux. Acta Meteol Sinica, 54(4):447-454

[21] Papaioannou G, Nikolidakis G, Asimakopoulos D, Retalis D (1996) Photosynthetically active radiation in Athens. Agric For Meteorol, 81:287-298. https://doi.org/10.1016/0168-1923(95)02290-2.

[22] Zhang X, Zhang Y, Zhao Y (2000). Measuring and modeling photosynthetically active radiation in Tibetan Plateau during AprilOctober. Agric For Meteorol, 102:207-212. https://doi.org/10.1016/S0168-1923(00)00093-9.

[23] Li R, Zhao L, Ding YJ, Wang S, Ji GL (2010). Monthly ratios of PAR to global solar radiation measured at northern Tibetan Plateau, China. Sol $\quad$ Energ, $\quad 84: 964-973$. https://doi.org/10.1016/j.solener.2010.03.005.

[24] Hu B, Wang YS, Liu GR (2007). Measurements and estimations of photosynthetically active radiation in Beijing. Atmo Res, 85:361371. https://doi.org/10.1016/j.atmosres.2007.02.005.

[25] Finch DA, Bailey WG, McArthu LJB, Nasitwitwi M (2004). Photosynthetically active radiation regimes in a southern African savanna environment. Agric For Meteorol, 122:229-238. https://doi.org/10.1016/j.agrformet.2003.09.015.

[26] Xia X, Li Z, Wang P, Cribb M, Chen H, Zhao Y (2008). Analysis of photosynthetic photon flux density and its parameterization in Northern China. Agric For Meteorol, 148:1101-1108. https://doi.org/10.1016/j.agrformet.2008.02.008.

[27] Howell TA, Meek DW, Hatfield JL (1983). Relationship of photosynthetically active radiation to shortwave radiation in the San Joaquin Valley. Agric For Meteorol, 28:157-175. https://doi.org/10.1016/0002-1571(83)90005-5.

[28] Wang L, Gong W, Lin A, Hu B. Analysis of photosynthetically active radiation under various sky conditions in Wuhan, Central China 2013; http://dx.doi:1007/500484-013-0775-3; Int J. Biometeorol.

[29] Udo SO, Aro TO (1999). Global PAR related to global solar radiation for central Nigeria. Agric For Meteorol, 97:21-31. https://doi.org/10.1016/S0168-1923(99)00055-6.

[30] Anjorin OF, Utah EU, Likita MS. (2014). Estimation of hourly photosynthetically active radiation (PAR) from hourly global solar radiation (GSR) in Jos, Nigeria. Asi. Revi. Environ. And Eart. Sci., 2: 43-50.

[31] Nwokolo SC \& Ogbulezie JC. (2017). A single hybrid parameterbased model for calibrating Hargreaves-Samani coefficient in Nigeria. International Journal of Physical Research, 5(2): 49-59. https://doi.org/10.14419/ijpr.v5i2.8042.

[32] National Aeronautics and Space Administration (NASA) atmospheric science data center, http://eosweb.larc.nasa.gov/see/.

[33] Iqbal M (1983). An introduction to solar radiation. First Edition. Academic Press.

[34] Miskolczi F., T.O. Aro, M. Iziomon, R.T. Pinker (1997). Surface radiation fluxes in Sub-Sahel Africa. Journal of Applied Meteorology. 36:521-530. https://doi.org/10.1175/15200450(1997)036<0521:SRFISS >2.0.CO;2.

[35] Babatunde EB. Solar radiation modeling for a tropical station, Ilorin, Nigeria. PhD. Thesis 32-34, 2001.

[36] Babatunde EB, Aro TO. (2001). Characteristics variation of total solar radiation at Ilorin, Nigeria. Nig. J. Sol. Ener., 9:157-173. 